\title{
Teknologi Tepat Guna TAKEDAPOT Sebagai Komponen Optimalisasi Pengembangan Rumah Pangan Lestari dan Sumber Pangan Sehat Kekebalan Tubuh di Masa Pandemi COVID-19
}

\author{
TAKEDAPOT Appropriate Technology as a Component of Optimization for the Development of \\ Sustainable Food Houses and Healthy Food Resources for Immunity in the \\ Pandemic Period of COVID-19 \\ Bambang Budi Santoso \\ Program Studi Agroekoteknologi, Fakultas Pertanian, Universitas Mataram, Mataram, INDONESIA
}

\author{
Article history \\ Received: 15 Maret 2020 \\ Revised: 25 Maret 2020 \\ Accepted: 11 Mei 2020 \\ *Corresponding Author: \\ Bambang Budi Santoso \\ Program Studi \\ Agroekoteknologi, Fakultas \\ Pertanian, Universitas \\ Mataram, NTB, \\ Indonesai; \\ Email: \\ bambang.bs@unram.ac.id.
}

\begin{abstract}
TAKEDAPOT (planting Moringa in pots) has an important meaning as a means of meeting the needs of healthy vegetables (food), providing sustainable food for at least families, as a means of preserving the resources of Moringas germplasms, as well as landscaping elements in the yard, and also can be relied upon as herbal ingredients to increase immune system which is now very much needed in connection with the COVID-19 pandemic. Intensive TAKEDAPOT planting certainly has an excess yield as an additional source of income. As a component of the optimization of the RPL (Sustainable Food Houses) program or KRPL (Sustainable Food Houses Area) TAKEDAPOT can be relied upon for the achievement of the program. With appropriate technology available TAKEDAPOT and if properly and properly implemented, at least food security will be achieved, where everyone, at all times, has physical and economic access to sufficient, safe and nutritious food, to meet their needs and preferences the food they need and as a food source for immune enhancement.
\end{abstract}

Keywords: horticulture; moringa; pruning; the yard; vegetable

Abtrak: TAKEDAPOT (tanam kelor dalam pot) memiliki arti penting sebagai sarana pemenuhan kebutuhan sayuran (pangan) sehat, penyediaan pangan yang berkelanjutan untuk paling tidak keluarga, sebagai sarana pelestarian sumberdaya tanaman kelor, serta sebagai element lansekap pekarangan, dan juga dapat diandalkan sebagai bahan herbal meningkatkan kekebalan tubuh yang saat sekarang sangat dibutuhkan sehubungan dengan pandemic COVID-19. Penanaman TAKEDAPOT yang intensif sudah pasti kelebihan hasil panenan dapat sebagai sumber pendapatan tambahan. Sebagai komponen optimalisasi program RPL (Rumah Pangan Lestari) ataupun KRPL (Kawasan Rumah Pangan Lestari) TAKEDAPOT dapat diandalkan bagi tercapainya program tersebut. Dengan teknologi tepat guna TAKEDAPOT yang telah tersedia dan jika diterapkan, paling tidak ketahanan pangan akan dicapai, dimana setiap orang, setiap saat, memiliki akses fisik dan ekonomi kepada pangan yang cukup, aman, dan bergizi, untuk memenuhi kebutuhan dan preferensi makanan yang mereka butuhkan dan sebagai sumber pangan peningkat kekebalan tubuh.

Kata kunci: horticulture; moringa; pruning; the yard; vegetable 


\section{PENDAHULUAN}

Salah satu prioritas pembangunan pertanian adalah ketersediaan pangan dalam jumlah yang cukup sepanjang waktu. Bahkan untuk ketercukupan pangan tersebut, setiap rumah tangga diharapkan mengoptimalisasi sumberdaya yang dimiliki, termasuk pekarangan, dalam menyediakan pangan bagi keluarga. Oleh karena itu, maka Kementerian Pertanian menginisiasi optimalisasi pemanfaatan pekarangan melalui konsep Rumah Pangan Lestari (RPL). RPL adalah rumah penduduk yang mengusahakan pekarangan secara intensif untuk dimanfaatkan dengan berbagai sumberdaya lokal secara bijaksana yang menjamin kesinambungan penyediaan bahan pangan rumah tangga yang berkualitas dan beragam (Kementan, 2012).

Lebih lanjut Kementan (2012) menguraikan bahwa prinsip dasar RPL yang dikembangkan berbasis kawasan atau KRPL (Kawasan Rumah Pangan Lestari) meliputi (i) pemanfaatan pekarangan yang ramah lingkungan dan dirancang untuk ketahanan dan kemandirian pangan, (ii) diversifikasi pangan berbasis sumber daya lokal, (iii) konservasi sumberdaya genetik pangan (tanaman, ternak, ikan), dan (iv) menjaga kelestariannya melalui kebun bibit desa menuju (v) peningkatan pendapatan dan kesejahteraan masyarakat. Dan kemudian dikatakan pula bahwa beberapa faktor lain yang mendukung keberlanjutan KRPL adalah ketersediaan benih/bibit, penanganan pascapanen dan pengolahan, dan pasar bagi produk yang dihasilkan. Dengan kata lain, diperlukan paket teknologi tepat guna dalam rangka pemanfaatan pekarangan sebagai komponen pendukung keberhasilan RPL.

Beberapa tahun belakangan ini salah satu tanaman sumber pangan sehat yang mendapat perhatian luas adalah tanaman kelor (Moringa oleifera Lam.). Budidaya atau pengembangan tanaman kelor secara intensif di Indonesia belum berkembang dengan baik dan meluas, kecuali oleh pengusaha untuk keperluan pemenuhan industrinya.

Tidak saja sebagai sumber sayuran segar yang sehat, daun kelor merupakan bahan baku produk herbal yang manfaatnya mampu meningkatkan daya tahan tubuh agar tidak mudah terkena penyakit. Daun kelor mempunyai manfaat kesehatan sehubungan dengan terkandung antioksidan, yaitu senyawa yang dapat melawan radikal bebas di dalam tubuh. Selain antioksidan, di dalam daun kelor terkandung pula vitamin C dan beta-karoten, serta quercetin dan asam klorogenat yang mampu menurunkan tekanan serta kadar gula darah. Oleh karena itu, ditengah-tengah musibah pendemi corona, maka dengan mengkonsumsi daun kelor baik dalam bentuk segar maupun produk olahannya akan meningkatkan meningkatkan sistem kekebalan tubuh untuk mencegah terpapar COVID-19.

Melalui program RPL ataupun KRPL, maka pemanfaatan tanaman kelor untuk dikonsumsi daunnya tentu akan sangat bermanfaat dalam pemenuhan sumber pangan (sayuran) sehat secara mandiri. Penanaman tanaman kelor dengan teknik bertanam yang fleksibel, kompak, dan portable adalah Teknik Bertanam Tanaman Kelor Dalam Pot atau TAKEDAPOT. Pada pekarangan yang umumnya relatif sempit di perkotaan ataupun pekarangan di perdesaan, TAKEDAPOT dapat sebagai elemen lansekap yang memperindah halaman atau taman pekarangan. Khususnya pada daerah lahan kering TAKEDAPOT akan sangat menguntungkan sehubungan dengan pemanfaatan air siraman yang lebih efisien dan menghadirkan hijauan yang meningkatkan suasana kesegaran di halaman rumah (Santoso et al. 2019).

Bertanam TAKEDAPOT memiliki arti penting yang cukup luas, tidak saja sebagai pemenuhan kebutuhan akan sayur (pangan) sehat, namun juga sebagai sarana penyediaan pangan yang berkelanjutan untuk paling tidak keluarga, sebagai sarana pelestarian sumberdaya tanaman kelor, serta jika ditujukan sebagai element lansekap pekarangan, tanaman kelor dalam pot juga dapat diandalkan. Jika penanaman TAKEDAPOT cukup banyak dan disertai dengan perawatan yang baik, maka kelebihan hasil panenan tentunya dapat dijual. Hal ini menjadi salah satu peluang usaha yang mendatangkan tambahan pendapatan bagi rumah tangga. Jadi, TAKEDAPOT dapat dijadikan sebagai komponen agar optimalisasi program RPL ataupun KRPL dapat berhasil dengan baik. Dengan TAKEDAPOT, paling tidak ketahanan pangan akan dicapai, dimana setiap orang, setiap saat, memiliki akses fisik dan ekonomi kepada pangan yang cukup, aman, dan bergizi, untuk memenuhi kebutuhan dan preferensi makanan yang mereka butuhkan.

Berikut ini adalah uraian hasil penelitian penulis dari berbagai percobaan pengembangan tanaman kelor, yang kemudian menghasilkan beberapa buku (monograp) seperti Pembibitan Tanaman Kelor (Moringa 
oleifera Lam.), Biji dan Teknologi Benih Kelor (Moringa oleifera Lam.), dan TAKEDAPOT-Tanam Kelor Dalam Pot. Kemudian, dari buku-buku tersebut diuraikan suatu paket teknologi tepat guna khususnya pada kesempatan ini TAKEDAPOT untuk optimalisasi pengembangan Kawasan Rumah Pangan Sehat, sekaligus sumber pangan peningkat kekebalan tubuh.

\section{TINJAUAN KESEHATAN DAUN KELOR}

Daun kelor memiliki beberapa manfaat bagi tubuh. Badan Pangan Dunia (FAO) menetapkan kelor sebagai Crop of the Month (pangan bulan ini) pada 2018, karena kandungan gizinya. Kelor kaya akan protein, vitamin A, B, C dan berbagai mineral, serta antioksidan. Berikut beberapa di antaranya, dirangkum dari Anwar et al. (2007), Fahey (2005), Becker and Siddhuraju (2003), dan Foidl et al. (2001);

Agen antioksidan. Daun kelor memiliki sifat antioksidan yang mampu melindungi tubuh dari serangan radikal bebas. Sifat antioksidan yang tinggi mampu meningkatkan daya tahan tubuh lebih kuat sehingga mampu menangkal berbagai penyakit, seperti penyakit kronis termasuk menurunkan risiko terjangkit penyakit diabetes tipe- 2 dan penyakit jantung.

Mengatasi stress. Kandungan asam amino tripofan yang ada dalam daun kelor berguna untuk membuat tubuh menjadi lebih rileks (rileksasi). Jika badan dan pikiran mengalami stres, maka otomatis imunitas tubuh turun.

Agen antibakteri. Sifat antibakteri yang ada dalam daun kelor mampu menghambat perkembangan mikroorganisme berbahaya yang ada dalam tubuh. Mikroorganisme yang berkembang dalam tubuh mampu merusak jaringan dalam tubuh dan menimbulkan berbagai gangguan kesehatan.

Mengatasi peradangan. Konsumsi daun kelor secara teratur mampu meredakan peradangan yang terjadi dalam tubuh, sehubungan dengan adanya kandungan isotiosianat yang berperan sebagai zat antiinflamasi.

Mengatur kadar kolesterol. Konsumsi daun kelor mampu menurunkan kadar kolesterol jahat (LDL). Kandungan zat hiocarbamate glikosida dan nitrile yang ada dalam daun kelor juga berperan sebagai menurunkan tekanan darah di dalam tubuh.

Mengatasi diabetes. Daun kelor dapat mengatasi diabetes karena kandungan insulin alami yang ada di dalam daun kelor. Selain itu, dapat mencegah penyakit gula dan mengurangi kadar gula dalam darah menjadi stabil.

Meningkatkan sistem kekebalan tubuh. Selain berguna untuk mengatasi stres, kandungan asam amino pada daun kelor juga berperan penting untuk menjaga sistem pencernaan tubuh. Kandungan nutrisi yang ada dalam daun kelor berfungsi efektif memperbaiki segala kerusakan pada jaringan tubuh dan proses pertumbuhan, yang pada akhirnya meningkatkan kekebalan tubuh.

\section{TINJAUAN AGRONOMIS TAKEDAPOT}

TAKEDAPOT membutuhkan persyaratan seperti sinar matahari dan pot yang dapat memfasilitasi jeluk perakaran yang cukup luas. Persyaratan mutlak adalah sinar matahari sekitar 5-6 jam dan sirkulasi udara yang memadai. Setelah persyaratan ini terpenuhi, maka TAKEDAPOT dapat ditempatkan di mana saja dengan aman. Kesuksesan TAKEDAPOT tidak lepas dari dapat tidaknya penanam memenuhi kebutuhan dasar tanaman; yaitu media tumbuh yang memadai, cahaya yang cukup, suhu yang tepat dan kelembaban serta nutrisi yang diperlukan.

Tanaman kelor memiliki beberapa karakter yang cocok dan menguntungkan sebagai TAKEDAPOT. Tanaman kelor memiliki persyaratan sebagai tanaman tahunan yang dipelihara di dalam wadah (pot), yaitu mudah dirawat, tahan kekeringan dan daya adaptasi yang luas, serta dapat tumbuh pesat untuk menghasilkan daun sebagai hasil utama TAKEDAPOT.

Karakter-karakter tanaman kelor yang menjadikan atau membuat tanaman ini dapat sebagai TAKEDAPOT adalah sebagai berikut: 
1. Umur menghasilkan produk berupa biomasa daun sangat singkat (genjah), walaupun bahan tanam berupa bibit berasal dari stek batang maupun berasal dari biji.

2. Habitus tanaman kelor mudah direkayasa untuk tumbuh atau berpenampilan lebih pendek maupun lebih lebar.

3. Tahan terhadap pemangkasan. Pemangkasan adalah teknik panen daun kelor.

4. Produktivitas daun sangat pesat, dikarenakan sifat regrowth tanaman kelor sangat baik.

5. Daya adaptasi terhadap lingkungan tumbuh cukup luas, yakni dapat tumbuh baik walaupun dalam wadah. Tahan kekeringan sehingga tidak memerlukan air siraman yang banyak.

6. TAKEDAPOT dapat dijadikan atau dimanfaatkan juga sebagai elemen lansekap pekarangan, karena nilai estetika atau keindahan kanopi tanaman dan juga warna hijau yang menimbulkan kesegaran dan kesejukan.

7. Dapat digunakan untuk memanfaatkan halaman atau lahan yang sempit yang sekaligus dapat pula dipindah-pindah sesuai keinginan.

8. Mudah dalam melakukan perawatan tanaman.

9. Sangat cocok untuk program penghijauan pekarangan berbasis pangan sehat dan herbal ataupun program penyediaan pangan sehat berbasis keluarga.

10. Pertumbuhan dan perkembangan tanaman tidak merusak bangunan yang ada di sekitarnya.

11. Kebutuhan unsur hara mineral dan air dapat dipenuhi secara optimal dan efisien.

12. Dapat sebagai sumber penghasilan dengan menjual bibit atau daun maupun buah yang dihasilkan.

\section{MENYIAPKAN BIBIT}

Pembibitan tanaman kelor dilakukan di pesemaian dapat berupa bibit asal biji dan bibit berasal dari stek batang. Bibit yang baik merupakan jaminan pasti bagi keberhasilan TAKEDAPOT.

Berikut adalah tahapan pelaksanaan pembibitan tanaman kelor asal biji untuk keperluan TAKEDAPOT;

1. Persiapan media pesemaian dan pembibitan

Media pembibitan yang disediakan terdiri dari media tabur dan media sapih (media pembibitan dalam polibag). Media tabur atau semai menggunakan media campuran dari tanah lapisan olah-pasir kali-sekam. Sedangkan media sapih menggunakan media campuran tanah lapisan olah-kompos atau bahan organik limbah pertanian dengan perbandingan 1:1 (v/v). Tanah untuk media sapih yang baik adalah tanah yang gembur dan halus.

2. Penaburan Benih

Penaburan benih pada media semai dapat dilakukan secara langsung ke polibag (pembibitan langsung) atau penaburan ke bak kecambah terlebih dahulu (pembibitan tidak langsung).

Benih dibenamkan (1-2 cm) pada media, kemudian ditutup dengan media tersebut. Benih kelor sudah mulai terlihat tumbuh di permukaan media sekitar 5-7 hari sejak penanaman, dan periode semai akan berakhir antara 15-17 hari sejak penanaman.

3. Pemeliharaan Semai

Pemeliharaan pesemaian diperlukan hingga semai siap disapih, dengan ciri semai telah memiliki calon batang yang tegak, sehat, dan memiliki daun yang telah mulai mekar (1-2 helai). Pemeliharan semai merupakan tindakan menjaga agar media semai tetap basah melalui kegiatan penyiraman. Penyiraman dilakukan dengan cara menuangkan air secara perlahan di posisi pinggir bak semai atau dengan cara dileb jika menggunakan bedengan. 


\section{Persiapan Media Sapih (Pembibitan)}

Media pembibitan yang baik tentu media yang dapat mendukung pertumbuhan bibit dengan baik sehingga menghasilkan bibit tanaman kelor yang berkualitas. Untuk memperkaya kecukupan unsur hara pada media sapih, media tanah berupa tanah lapisan olah dicampur dengan kompos, atau pupuk kandang.

Media campuran tersebut kemudian dimasukkan ke dalam polibag berwarna hitam ukuran diameter $16 \mathrm{~cm}$ dan tinggi $20 \mathrm{~cm}$ (ukuran untuk bibit hingga umur 2 bulan) atau ukuran diameter $25 \mathrm{~cm}$ dan tinggi $30 \mathrm{~cm}$ (untuk bibit umur 3 bulan).

5. Pindah Tanam Semai

Pindah tanam semai atau penyapihan dilakukan setelah semai memiliki 1-2 daun, berbatang tegak tinggi sekitar 5-7 cm, dan sehat. Semai dicabut dan kemudian ditanam dalam media polibag lalu media di sekitar lubang tanam dipadatkan seperlunya agar semai berdiri tegak. Polibag berisi semai kemudian disusun rapi di bedeng pembibitan di areal yang tidak terkena cahaya matahari yang terik, atau sebaiknya di bawah atau di antara naungan alami dengan intensitas cahaya masuk 70-80 persen.

6. Pemeliharaan Bibit

Penaungan bibit pada awal pertumbuhannya bertujuan untuk menjaga semai yang baru dipindah-tanam dari terpaan terlalu teriknya cahaya matahari. Pengurangan intensitas naungan mulai dilakukan saat bibit berumur 2 minggu setelah sapih. Intensitas cahaya diperlukan lebih banyak agar pertumbuhan bibit kelor lebih kokoh. Intensitas cahaya berkisar 80-85 persen, kemudian setelah umur satu bulan penaung dibuka. Pemupukan pada bibit dilakukan pertama kali setelah bibit berumur minimal 14-16 hari setelah pindah semai. Gunakan pupuk majemuk (NPK) 15:15:15 atau dapat juga 16:16:16 dengan dosis 5 g/polibag. Untuk mengendalikan kejadian serangan hama-penyakit, sebaiknya pembibitan diupayakan jangan terlalu lembab atau tergenang air. Lubang drainase di sekitar pembibitan ataupun media dalam polibag harus baik jangan sampai tersumbat.

Berikut adalah uraian ringkas tahapan pelaksanaan pembibitan tanaman kelor secara vegetatif atau perbanyakan tanaman kelor dengan mengunakan stek batang;

1. Menyiapkan Media Tumbuh

Media perbanyakan tanaman kelor dengan stek batang kelor dapat menggunakan pasir, serbuk sabut kelapa (cocopeat atau cocodust), ataupun bahan organik lainnya (limbah pertanian seperti hancuran tongkol jagung, sekam padi, dan serbuk gergajian kayu). Bahan-bahan media organik tersebut dicampur dengan tanah untuk menghasilkan media campuran yang baik bagi pertumbuhan bibit asal stek batang, yaitu dengan perbandingan 1:1:1 (v/v). Media campuran tersebut, kemudian dimasukan ke polibag dan disusun membentuk bedengan dengan ukuran 1 x 5 meter.

\section{Persiapan Naungan}

Pembibitan tanaman kelor dengan menggunakan stek batang memerlukan penaungan (pencahayaan sekitar 80-85 persen) terutama pada periode satu bulan pertama. Periode tersebut merupakan periode dimana tunas mulai tumbuh dan berkembang demikian pula halnya dengan akar. Pada saat itu kelembaban yang diperlukan cukup tinggi dan suhu yang diperlukan cukup rendah.

\section{Menanam Stek}

Penanaman stek dilakukan dengan cara membuat lubang tanam terlebih dahulu pada media dalam polibag, kemudian satu stek batang ditanam untuk tiap polibag. Media tanam dalam polibag sebaiknya satu hari sebelum tanam stek, disiram terlebih dahulu. Setelah polibag ditanami stek, polibeg-polibeg tersebut ditata membentuk bedengan. 


\section{Pemeliharaan Pembibitan}

Setelah penanaman stek batang selesai dilakukan, kemudian lakukan penyiraman. Penyiraman minggu pertama sampai minggu kedua dilakukan setiap 2 hari sekali, kemudian seminggu 2 kali sampai stek berakar (setelah 2-3 minggu) tergantung besar-kecil ukuran stek batang yang digunakan.

Penaungan pembibitan dapat dibuka jika bibit telah berumur 1-1,5 bulan. Sebelum naungan dibuka, pembibitan disiram terlebih dahulu.

Hindari benturan yang menyebabkan stek batang goyang atau goyak, karena hal ini akan menyebabkan sistim perakaran yang baru tumbuh akan putus dari dasar stek. Sistim perakaran stek batang kelor yang baru tumbuh sangat lemah dan halus, sehingga mudah putus.

Pemupukan bibit tanaman kelor asal stek batang dilakukan 3-4 minggu setelah tanam. Pastikan bibit telah membentuk pertunasan dan perakaran. Pupuk yang digunakan jenis pupuk lengkap (NPK) seperti phonska 15-15-15 sebanyak 5 gram/polibag/bibit.

Sama halnya pada pembibitan menggunakan biji, pada pembibitan dengan stek batang, daun bibit sering diserang hama. Jika dilihat pada epidermis daun bagian bawah terlihat kutu berukuran sangat kecil, maka pembibitan tanaman kelor perlu disemprot dengan insektisida. Insektisida dengan bahan aktif karbaril dan yang berbahan aktif metomil, tampak cukup efektif mengendalikan serangan hama jenis ini. Aplikasi pemberian satu kali seminggu sebanyak 3 kali (tergantung kondisi serangan).

1. Jenis pot

\section{MENYIAPKAN POT TANAM}

Jenis atau bahan pot tentunya akan terkait dengan fasilitas draenase dan aerasi, walaupun pada dasarnya lubang draenase dapat dibuat terutama di dasar (bagian bawah) pot. Drainase yang memadai adalah persyaratan lain bagi TAKEDAPOT. Sebagian besar pot memiliki lubang drainase, tetapi seringkali dijumpai fasilitas ini tidak cukup memadai bagi terjadinya draenase yang baik. Oleh karena itu perlu dibuatkan sebagai lubang draenase tambahan.

Ada banyak jenis pot yang dapat digunakan untuk TAKEDAPOT, seperti pot tanah liat merah, pot kayu, pot plastik, pot beton, dan besi (drum), ataupun planter bag. Setiap jenis tentu memiliki kelebihan ataupun kekurangan. Selama penelitian berlangsung, penulis sangat dimudahkan terutama dalam hal kemudahan pengangkutan dan pemindahan serta pemeliharaan TAKEDAPOT jika menggunakan planter bag dan/atau pot plastik.

\section{Ukuran pot}

Menetapkan ukuran pot adalah merupakan keputusan ekonomi karena biaya produksi merupakan fungsi dari berapa banyak tanaman yang dapat ditanam di dalam pot dalam waktu tertentu. Pot yang lebih besar menempati ruang yang lebih besar dan membutuhkan waktu lebih lama untuk menghasilkan ukuran akar yang besar yang memenuhi pot. Oleh karena itu, tanaman dalam wadah yang lebih besar lebih mahal atau lebih banyak membutuhkan biaya produksi. Namun, tidak menutup kemungkinan manfaatnya mungkin lebih besar daripada biaya jika tujuan penanaman lebih berhasil dipenuhi.

Pot berukuran besar adalah yang terbaik untuk menanam TAKEDAPOT. Selama tanaman kelor terjamin atau pot memiliki ruang untuk perakaran yang cukup, TAKEDAPOT dapat memberikan hasil yang memuaskan seperti halnya tanaman ini biasanya tumbuh di tanah (di lapang). Pengaturan jumlah tanaman dalam pot merupakan hal sangat penting, sehubungan keterkaitannya dengan jumlah panenan yang memadai.

Tinggi pot. Tinggi pot menentukan kedalaman sistim perakaran (steker root). Ketinggian pot juga penting karena menentukan proporsi media tanam yang mengalir bebas dalam wadah. Ketika air siraman diberikan pada pot berisi media tanam, gravitasi meresapnya ke bawah hingga mencapai dasar dan habis keluar melalui lubang pembuangan di bagian dasar pot. Di daerah bagian bawah media tanam, air relatif terhenti atau melambat bergerak karena daya tarik (ikat) media tanam, akan menciptakan zona jenuh air yang selalu ada di bagian bawah pot. Tinggi pot mempengaruhi kedalaman (ketebalan) lapisan jenuh ini. Pada kondisi jenis media tanam yang sama, kedalaman lapisan jenuh selalu lebih besar secara proporsional pada 
pot yang lebih pendek. Jadi, jenis media juga mempengaruhi fenomena tersebut di atas. Semakin kuat daya pegang air oleh media tanam maka kedalaman lapisan jenuh akan semakin tinggi.

TAKEDAPOT merupakan bertanam jenis tanaman tahunan yang mempunyai sistem perakaran yang dalam sehingga membutuhkan pot yang dalam juga. Oleh karena itu, sebaiknya tidak menggunakan pot yang dangkal.

Diameter Pot. Pohon berdaun lebar, semak, dan tanaman herba membutuhkan diameter wadah yang lebih besar sehingga air irigasi yang diterapkan dari atas dapat menembus dedaunan yang lebat dan mencapai medium. Terkait dengan rencana penanaman TAKEDAPOT untuk tujuan diperolehnya hasil berupa daun yang tumbuh baik dan segar sebagai sumber pangan sehat, maka diameter pot yang lebih lebar diperlukan agar dapat menanam sejumlah 2-3 tanaman kelor dalam setiap potnya.

Bentuk Pot. Pot telah tersedia dalam berbagai bentuk dan sebagian besar diameternya mengecil dari atas ke bawah. Sebagian besar pot berbentuk bulat tetapi ada yang berbentuk persegi. Bentuk pot tidaklah begitu penting untuk rencana penanaman TAKEDAPOT. Kecuali jika rencana penanaman TAKEDAPOT juga disertai dengan rencana dekorasi halaman atau dijadikan sebagian dari komponen taman halaman. Untuk TAKEDAPOT, sebaiknya pilih pot yang mempunyai bentuk silinder dan tidak terlalu menyempit ke bawah untuk memberikan ruang yang cukup bagi pertumbuhan akar. Hindari, menggunakan pot yang mempunyai bibir (pinggir atas) yang terlalu melebar ke samping dan menyempit di bagian tengah.

\section{Jumlah Tanaman dalam Pot.}

Ini berarti pula sebagai pengaturan jarak tanam (lebih tepat dikatakan sebagai tata letak tanaman dalam pot) yang sangat penting untuk diperhatikan dalam TAKEDAPOT. Hal ini akan mempengaruhi jumlah cahaya, air, dan nutrisi yang tersedia untuk masing-masing tanaman.

Beberapa pengaruh dari kepadatan (populasi) rendah:

a. Tanaman lebih pendek dengan diameter batang yang lebih besar

b. Mudah dilakukan penyiraman dengan teknik sprinkle atau penyiraman dari atas

c. Sirkulasi udara dalam kanopi lancer, daun akan tumbuh lebih sehat

d. Kanopi akan tumbuh lebih baik dan sehat serta merata di antara daun di bagian atas dengan daun di bagian bawah

Beberapa pengaruh dari kepadatan (populasi) tinggi:

a. Tanaman lebih tinggi, berdiameter batang lebih kecil

b. Relatif lebih sulit disiram atau dipupuk dengan teknik sprinkle

c. Mudah terjangkit penyakit daun karena kurangnya pergerakan udara di dalam kanopi

d. Suhu media tumbuh lebih dingin

e. Daun-daun yang letaknya di bagian bawah akan mudah atau cepat gugur akibat pengaruh penaungan daun-daun yang ada di atasnya

\section{Macam media}

\section{MEDIA TANAM}

Media tanam adalah salah satu faktor penting yang menentukan keberhasilan TAKEDAPOT, karena sudah pasti bahwa media TAKEDAPOT jumlahnya dibatasi oleh volume pot, sehingga komposisi yang tepat akan membuat perakaran tanaman dapat berkembang dengan baik untuk menunjang pertumbuhan dan perkembangan tanaman.

Penggunaan media tanam TAKEDAPOT dengan komposisi yang ideal akan sangat menunjang pertumbuhan akar menjadi lebih optimal, akar dapat tumbuh dengan leluasa karena mendapatkan suplai oksigen dan air dalam jumlah memadai, dan dalam kondisi pertumbuhan optimal tersebut, akar dapat menjalankan fungsinya untuk menyerap air dan hara-hara yang diperlukan dari dalam media tanam untuk disinergikan dalam proses pertumbuhan dan per-kembangan tanaman.

Media tanam yang dapat digunakan dalam TAKEDAPOT tersedia dalam dua bentuk dasar, yaitu berbasis tanah dan berbasis organik. Jika keduanya dibandingkan maka, media berbasis tanah atau media 
dengan tanah sebagai komponen utama cenderung menghasilkan tanaman yang kurang baik tumbuhnya. Sedangkan pada media tanam berbasis organik (bahan dasar organik yang dapat berupa kompos, sekam, gambut, sabut kelapa, atau bahan organik lainnya, dicampur dengan bahan anorganik dapat berupa tanah) cenderung menghasilkan tanaman yang tumbuh lebih baik dan subur, dikarenakan media organik mendorong perkembangan akar yang lebih baik.

\section{Fungsi Media Tumbuh}

Media tanam yang baik untuk bertanam tanaman kelor dalam pot adalah yang memiliki empat fungsi sebagai berikut ini,

Fungsi Fisik. Media tanam harus berporos cukup sekaligus menjamin secara fisik tanaman akan tegak berdiri (kuat memegang sistim perakaran). Dengan jumlah tanaman yang ditanam lebih banyak pada setiap individu pot, media tanam harus cukup berat untuk menahan tanaman tegak lurus terhadap terpaanangin.

Aerasi. Akar tanaman membutuhkan pasokan oksigen yang stabil untuk mengubah fotosintat dari daun menjadi energi sehingga akar dapat tumbuh dan mengambil air dan mineral dalam jumlah banyak (cukup). Produk sampingan dari respirasi ini adalah karbon dioksida yang harus didispersikan ke atmosfer untuk mencegah penumpukan konsentrasi racun di dalam zona perakaran. Pertukaran gas ini terjadi di pori-pori besar (makropori) atau ruang udara pada media tanam. Karena tanaman kelor tumbuh dengan cepat, maka tanaman kelor membutuhkan media dengan porositas yang baik.

Pasokan Air. Tanaman menggunakan sejumlah besar air untuk tumbuh dan berkembang, dan pasokan air (ketersediaan air) ini harus disediakan oleh media tanam. Media tanam diformulasikan sehingga media tanam dapat menahan air pada pori-pori kecil (mikropori) di antara partikel-partikelnya. Oleh karena itu, media tanam harus memiliki porositas yang memadai untuk mampu menyerap dan menyimpan sejumlah besar air yang kemudian mudah pula melpaskannya jika dibutuhkan oleh tanaman yang sedang tumbuh.

Pasokan Nutrisi. Sebagian besar nutrisi mineral penting yang dibutuhkan tanaman untuk pertumbuhan yang cepat harus diperoleh melalui akar dari media tanam. Sebagian besar nutrisi mineral adalah ion. Ion bermuatan positif (kations) seperti ammonium $\left(\mathrm{NH} 4^{+}\right)$, kalium $\left(\mathrm{K}^{+}\right)$, kalsium $\left(\mathrm{Ca}^{+2}\right)$, dan magnesium $\left(\mathrm{Mg}^{+2}\right)$. Kation-kation ini bergerak ke lokasi bermuatan negatif pada partikel medium yang sedang tumbuh sampai pada titik akar mengekstrak kation.

\section{Media Campuran}

Media tanam TAKEDAPOT harus dapat menyimpan air dan memasok nutrisi yang dibutuhkan tanaman, namun juga harus mampu mendraenasenya dengan cepat air yang berlebih. Pada TAKEDAPOT sangat dianjurkan menggunakan media campuran. Gunakan campuran media campuran yang menyediakan drainase cepat dengan ruang udara yang cukup tetapi tetap mempertahankan kelembaban. Media campuran berbasis kompos sangat dianjurkan dalam TAKEDAPOT. Media tanam campuran berbasis kompos akan menyediakan komponen media yang dibutuhkan tanaman kelor untuk tumbuh dan berkembang dengan baik. Media tanam berbasis kompos akan memiliki sifat fisik, kimia, dan biologi yang baik. Karena alasan ini, bahan kompos selalu digunakan bersama dengan bahan lain untuk mempersiapkan media tanam campuran. Kompos yang dihasilkan dari limbah pertanian banyak digunakan sebagai komponen media tanam.

Media tanam yang baik agar tercapai tujuan penanaman TAKEDAPOT, maka lebih disarankan menggunakan media campuran tanah, sekam padi, dan seresah daun mambu dengan perbandingan campurannya 1:1:1 (v/v). Pada media campuran ini, selain menghasilkan daun yang lebih banyak, media campuran ini menghasilkan daun yang lebih hijau namun tidak kaku dan tebal. Campuran tanah dengan bahan organik dari limbah pertanian masih dapat digunakan untuk TAKEDAPOT. Media campuran tanah-cocopeat, tanahhancuran tongkol jagung, dan tanah-seresah daun bambu merupakan media terbaik dan lebih cocok bagi tanaman kelor pada sistim produksi TAKEDAPOT dibandingkan media tanah tunggal dan media campuran tanah-serbuk gergaji. 


\section{PENANAMAN}

Berikut adalah urutan mempersiapkan lubang tanam hingga penanaman bibit pada sistim produksi TAKEDAPOT,

1. Tentukan titik letak penanaman di dalam pot dengan mempertimbangkan jarak tanam yang dikehendaki (berkaitan dengan populasi tanaman per pot).

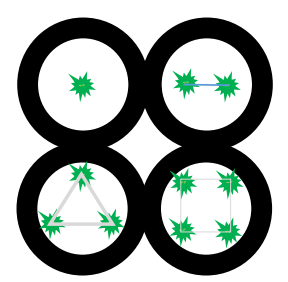

Gambar 1. Pola letak penanaman atau pengaturan jarak tanam TAKEDAPOT (1-4 tanaman per pot).

2. Gali lubang tanam dengan ukuran minimum $25 \times 25 \times 25 \mathrm{~cm}$ jika bibit yang akan ditanam berumur 1 bulan, atau 30x30x30 cm jika bibit yang akan ditanam berumur 2 bulan.

3. Taburkan pupuk fosfat seperti SP36 (Super Phosphat 36), di bagian bawah lubang tanam sebanyak 10-15 gram. Unsur fosfat dibutuhkan tanaman kelor untuk membentuk sistem perakaran yang kuat pada awal pertumbuhan tanaman sehingga tanaman akan tumbuh lebih baik dan lebih cepat.

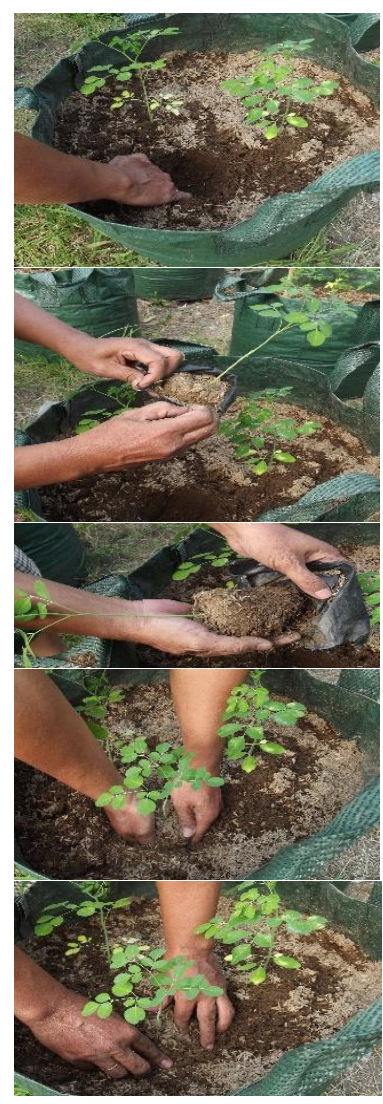

Membuat lubang tanam dengan ukuran lebih besar dari ongkahan media bibit yang akan dipindah tanam.

Merobek plastic polybag bibit dengan hatihati. Hindari bongkahan media perakaran mengalami kerusakan (hancur).

Sesegera memasukkan bibit beserta media ke lubang yang telah dipersiapkan.

Memadatkan media disekitar (di sekeliling) perakaran bibit dengan menekan-nekan media. Pastikan tanaman berdiri tegak dan kuat.

Gambar 2. Tahapan menanam kelor pada sistim TAKEDAPOT 
4. Robek plastik polibeg dan keluarkan bibit dari polybag, kemudian letakkan bibit pada bagian tengah lubang tanam dengan kedalaman yang disesuaikan.

5. Masukkan kembali campuran tanah (media) di sekeliling lubang, menutupi semua akar bibit hingga sebatas leher akar/batang bibit tersebut.

6. Padatkan tanah di sekeliling bibit agar bibit berdiri dengan tegak, tidak miring ke salah satu sisi yang dapat menyebabkan arah pertumbuhan tanaman menjadi jelek pada akhirnya.

7. Ulangi lagi langkah nomor 1 hingga nomor 6 , untuk tanaman kedua dan/atau ketiga dan/atau keempat, tergantung pada jumlah populasi tanaman per pot yang direncanakan.

8. Akhirnya, pemadatan tanah/media di sekeliling tanaman di dalam pot sangat diperlukan agar tanaman dapat berdiri dengan tegak dan kokoh. Media campuran yang digunakan untuk TAKEDAPOT merupakan jenis media campuran yang sangat gembur sehingga meski ditekan-tekan agar supaya cukup memadat. Selain itu pe-madatan media tanam juga bertujuan untuk mengisi semua ruang yang ada di bagian samping atau pinggir atau dinding pot yang mungkin belum terisi oleh media sehingga dapat dihindari media yang berlubang atau berongga besar saat dilakukan penyiraman.

9. Segera siramkan air dalam volume secukupnya (tidak lebih dari 5 liter) ke media dalam pot agar media menjadi basah dan jenuh oleh air, sekaligus menghindarkan tanaman menjadi layu setelah penanaman.

\section{Penyiraman}

\section{PEMELIHARAAN DAN PANEN}

Tujuan utama TAKEDAPOT adalah memproduksi atau menghasilkan daun, baik untuk keperluan konsumsi (sayur) ataupun sebagai bahan olahan keperluan herbal ataupun pangan olahan, serta bahan industri lainnya. Untuk produksi daun tersebut, konsekwensinya adalah diperlukan penyiraman secara teratur. Meskipun tanaman kelor ini terbilang tahan terhadap kekeringan, produksi daun relatif terganggu di saat musim kemarau panjang dengan ketersediaan fasilitas air terbatas. Pada kondisi tersebut, TAKEDAPOT akan kehilangan daunnya, tetapi tanaman tidak akan mati. Ketika mendapat pengairan yang rutin atau hujan telah turun, tanaman akan kembali tumbuh subur. Namun demikian, jika hujan sebagai andalannya, maka awal musim hujan tanaman kelor dalam pot sebaiknya dipangkas dan kemudian tambahkan pupuk organik (pupuk kandang atau kompos) untuk memastikan kembalinya pertumbuhan cabang dan daun yang sehat.

Pohon atau tanaman kelor dalam wadah tentu akan mengering jauh lebih cepat daripada yang tumbuh di tanah (lapang), oleh karena itu TAKEDAPOT perlu disiram secara teratur. Beberapa penyiraman mungkin diperlukan untuk memastikan kedalaman media tanam yang dapat terbasahi. Jumlah air yang diperlukan tersebut dijadikan ukuran setiap melakukan penyiraman.

Frekuensi peyiraman bergantung pada pertumbuhan akar maupun tajuk tanaman kelor. Untuk TAKEDAPOT memerlukan penyiraman dua hari sekali selama 3-4 minggu pertama setelah itu, penyiraman dapat dilakukan 3 hari sekali.

\section{Pengelolaan Media Tumbuh dan Pemupukan}

Penggantian media tanam TAKEDAPOT sebenarnya bukanlah hal mutlak yang harus dilakukan. Meskipun media tanam TAKEDAPOT tidak pernah diganti, namun jika pemberian nutrisi baik organik dan juga anorganik dilakukan secara teratur dan dalam jumlah yang cukup, TAKEDAPOT akan tetap tumbuh dan berkembang dengan baik, sehingga produksi daun dapat berkelanjutan hingga siklus produksi yang panjang.

Penggantian media tanam pada TAKEDAPOT dapat dilakukan dengan dua cara. Cara pertama, adalah penggantian media tanam sekaligus penggantian ukuran pot yang lebih besar, atau sering dikenal sebagai repotting. Cara kedua, adalah dengan penggantian media tanam tanpa diikuti dengan penggantian pot, yang berarti harus dilakukan pengurangan massa akar dari volume akar sebelumnya agar diperoleh ruangan baru untuk mengganti media tanam yang juga baru. Cara kedua ini sebaiknya dilakukan dengan mengerok media tanam di bagian atas (sekitar kedalaman 10-15 cm), lalu kemudian memasukkan media baru.

Mempertahankan ukuran tanaman kelor dalam pot agar tetap sesuai dengan ukuran pot akan memperpanjang masa produksi TAKEDAPOT. Hal ini dikarenakan ukuran pohon sebanding dengan ukuran 
sistem akarnya. Pot biasanya akan membatasi pertumbuhan akar sehingga diperlukan pembaruan media tanam dengan cara yang diuraikan di atas.

Memupuk sudah pasti bertujuan untuk mencukupi kebutuhan tanaman akan unsur hara esensial, agar tanaman dapat tumbuh baik secara vegetatif (akar dan batang) maupun generatif (bunga dan buah). Agar kelor pada sistim produksi TAKEDAPOT menghasilkan daun dalam jumlah besar, media tanaman kelor harus diberikan pupuk. Menambahkan kompos atau pupuk kandang sebagai sumber unsur hara sekaligus pembenah tanah (media) sangat diperlukan untuk pemeliharaan pertumbuhan TAKEDAPOT.

Penambahan unsur pupuk (nutrient) ke dalam media tanam TAKEDAPOT atau pemupukan dilakukan secara bertahap dan berkelanjutan. Pemupukan pertama kali dilakukan ketika media tanam disiapkan, yaitu sekitar 5-6 kg kompos atau pupuk kandang per $\mathrm{m}^{2}$ atau setara dengan sekitar 50-60 ton per ha. Selanjutnya, pemupukan berikutnya dengan pupuk kandang atau kompos setahun sekali sebanyak 1-2 $\mathrm{kg}$ setiap tanaman yang ditumbuhkan dalam sistim TAKEDAPOT. Sebaiknya dilakukan pada saat awal musim hujan. Pemupukan susulan tersebut (pada tahun ke 2-3) dapat dilakukan sekaligus dengan tindakan penggantian media tanam cara kedua (telah dijelaskan di atas). Jika ketersediaan pupuk kandang atau kompos relatif sulit di saat awal (memulai) menanam, yaitu di saat persiapan media, maka pemupukan awal dapat dilakukan dengan menggunakan $3 \mathrm{~g} /$ pot Urea, $1 \mathrm{~g} /$ pot SP36, dan $1 \mathrm{~g} /$ pot $\mathrm{KCl}$. Tiga bulan memudian pemupukan susulan dengan memberikan $2 \mathrm{~g} / \mathrm{pot} /$ tanaman Urea, $1 \mathrm{~g} /$ pot/ tanaman SP36, $1 \mathrm{~g} /$ pot/tanaman $\mathrm{KCl}$, dan $500 \mathrm{~g} / \mathrm{pot}$ pupuk kandang atau kompos. Pemupukan susulan tersebut kemudian diulang setiap 3 bulan sekali hingga TAKEDAPOT berumur 1-1,5 tahun. Setelah TAKEDAPOT berumur 2 tahun, disarankan memberikan pupuk susulan dengan dosis ditingkatkan dua kali lipat.

\section{Pemangkasan}

Bagi tanaman-tanaman yang organ atau bagian yang dipanen berada pada setiap pucuk percabangan (pucuk setiap tunas yang terbentuk) seperti halnya pada tanaman kelor, bahwa pemangkasan secara umum dapat meningkatkan jumlah cabang yang terbentuk, dan dengan semakin banyaknya jumlah cabang sekunder yang terbentuk dapat memberikan pengaruh positif terhadap jumlah daun. Pemangkasan akan menyebabkan dominansi apikal terhenti (atau pematahan efek dominasi apikal), selanjutnya akibat dominansi apikal yang terhenti menyebabkan auksin terakumulasi dan terdistribusi ke meristem lain yang ada di bawahnya sehingga terbentuk tunas-tunas lateral dalam jumlah yang banyak.

Pemangkasan pada TAKEDAPOT ada dua macam. Pertama, pangkas untuk panenan daun, dan kedua, pemangkasan ranting-ranting yang tidak diinginkan untuk tetap tumbuh atau berada pada kanopi tanaman.

Ketika tanaman kelor baik yang tumbuh di lapang maupun yang ditanam dalam pot dipangkas, tanaman akan tumbuh (bertunas) kembali dengan subur dan vigor sehingga menghasilkan lebih banyak percabangan dengan daun yang hijau segar. Pemangkasan pertama kali dilakukan dapat saja hanya bertujuan untuk merangsang pertunasan awal. Dalam hal ini daun hasil pangkasan tidak dimanfaatkan untuk konsumsi. Namun demikian, daun hasil pangkasan tersebut dapat juga dimanfaatkan untuk tujuan olahan (contoh untuk dijadikan tepung daun maupun sibuat teh daun kelor). Pangkas yang dimaksud ini adalah pangkas pertama di saat tanaman telah berumur 50-60 hari sejak tanam. Biasanya tanaman kelor pada umur ini hanya memiliki satu batang utama, sehingga hasil pangkasan hanya berupa satu potongan tunas apikal yang padanya terdapat 5-6 daun.

Pada umumnya, tinggi posisi pangkasan pertama tanaman hortikultura akan mempengaruhi pertumbuhan cabang berikutnya yang sekaligus mem-pengaruhi banyak-sedikitnya pangkasan (panenan) berikut-nya. Namun, hasil penelitian pada tanaman kelor yang ditanam di lapang (sawah tadah hujan di kawasan Amor-Amor, Kabupaten Lombok Utara, Nusa Tenggara Barat) menunjukkan bahwa perbedaan tinggi pemangkasan berpengaruh tidak nyata terhadap hampir semua parameter pertumbuhan cabang-cabang yang terbentuk sebagai respon pemangkasan tersebut. Perbedaan tinggi pangkasan berpengaruh tidak nyata terhadap pertumbuhan dan hasil biomassa daun kelor. Demikian pula halnya dengan pemangkasan pada TAKEDAPOT, perbedaan tinggi pangkasan berpengaruh tidak nyata pada bobot biomasa daun saja, maupun jumlah cabang, panjang cabang, dan jumlah daun. 
Jadi, tinggi pemangkasan yang berbeda dapat menghasilkan biomassa daun yang sama bobotnya. Tinggi pemangkasan pada batang utama tanaman kelor disarankan pada ketinggian $25 \mathrm{~cm}$ dari atas permukaan tanah, karena dengan tinggi pemangkasan ini disamping menghasilkan pertumbuhan dan biomassa daun yang baik dan subur, juga akan memudahkan dalam perawatan, pemanenan, dan batang hasil pangkasan masih dapat berpotensi digunakan untuk bahan perbanyakan tanaman kelor secara vegetatif.

Pemangkasan atau dalam hal ini pemanenan TAKEDAPOT yang baik dan rutin dapat mempengaruhi pertumbuhan perakaran yang baik pula. Hal ini sangat penting sehubungan TAKEDAPOT merupakan sistim produksi tanaman kelor pada tempat tumbuh yang dibatasi, seluas ukuran pot yang digunakan. Pada keadaan ini pertumbuhan akar akan terbatas dan memungkinkan pula membatasi pertumbuhan tajuk yang merupakan komponen utama hasil daripada TAKEDAPOT.

Pemangkasan akar adalah teknik yang mirip dengan bonsai dan akan membantu menjaga tanaman kelor tetap tumbuh relatif kecil bila dibandingkan jika ditanam di lapang. Pemangkasan akar dilakukan bersamaan dengan pergantian pot (dari ukuran kecil ke ukuran besar) ataupun hanya sebagian kecil akar yang dipangkas dengan cara dan saat penambahan (pergantian sebagian) media tanam. Lihat penjelasan pada sub bab pengelolaan media tanam dan pemupukan di atas.

Akar dan tunas suatu tanaman akan selalu tumbuh seimbang. Setelah pemangkasan dilakukan, tanaman (tunas) akan tumbuh kembali untuk membangun kembali keseimbangan pertumbuhan ini. Penting untuk memangkas tajuk atau tunas yang tumbuh tidak subur atau tidak menguntungkan, agar supaya sumberdaya tumbuh yang berasal dari akar dapat digunakan untuk pemeliharaan ataupun pertumbuhan yang lebih baik bagi pertunasan (tajuk) yang telah tumbuh baik tersebut.

Pada siklus produksi tahun kedua atau ketiga, pangkas kembali pada ketinggian 50-75 cm dari permukaan media tanah untuk tujuan mempertahankan ke-tinggian tanaman agar mudah dilakukan pemanen. Bilamana TAKEDAPOT diharapkan untuk membentuk 2-3 cabang utama maka panen (pemangkasan) pada siklus produksi ini dilakukan terhadap $2 / 3$ bagian cabang, atau meninggalkan panjang cabang sekitar 10-20 $\mathrm{cm}$.

Ini penting bagi TAKEDAPOT yang bertujuan untuk produksi daun. Jika dibiarkan tumbuh secara alami, pohon kelor memiliki kecenderungan untuk menghasilkan batang utama yang tinggi dan hanya menghasilkan daun di sekitar apikal dan sub-apikal. Hal in tentu akan menyebabkan hasil biomassa daun yang dapat dipanen hanya sedikit. Oleh karena itu sangat penting untuk merangsang pembentukan cabang lateral yang memberikan kelimpahan bercabangan beserta daun-daunnya yang berdampak pada tingginya biomassa daun yang dapat dipanen.

\section{Pengendalian Hama-Penyakit}

Beberapa jenis hama yang sering menyerang pohon kelor pada areal dimana tanaman ini banyak tumbuh dan berkembang adalah tungau, rayap, aphid, dan ulat. Sedangkan jenis penyakit yang dijumpai menyerang tanaman kelor adalah busuk akar disebabkan oleh jamur busuk akar, Diplodia $s p$.

Biasanya untuk hama serangga yang menyerang tanaman hortikultura lainnya dikendalikan dengan meng-gunakan insektisida. Sehubungan dengan tanaman kelor merupakan tanaman yang diambil daunnya untuk dikonsumsi maupun diolah (diproses), maka yang harus diperhatikan jika tanaman kelor terserang hama ataupun penyakit, sedapat mungkin menggunakan insektisida organik atau biologi, karena penggunaan insektisida kimia dapat menimbulkan kontaminasi residu bahan aktif yang membahayakan kesehatan konsumen.

Pada areal pertanaman kelor yang diusahakan dengan intensif, beberapa jenis hama yang dijumpai berpotensi mengurangi hasil adalah berupa ulat Eupterote molifera, Heliothis armiigera, kutu daun Zonocerus variagatus, aphids, dan juga rayap. Sementara itu, penyakit yang sering dijumpai adalah penyakit busuk akar Diplodia spp. Penyakit ini sering muncul pada kondisi buruknya draenasi di pertanaman.

Untuk mengendalikan atau menekan serangan hama, sebaiknya dilakukan dengan jadwal panen yang rutin dan benar. Hal ini jika dilakukan dengan baik akan mengurangi keberadaan dedaunan tanaman kelor yang terus menerus sepanjang waktu ataupun menjaga kelembaban yang aman bagi berkembangkan serangga hama maupun penyakit. Jadi dengan melakukan panenan yang baik dan teratur lebih disarankan daripada 
menggunakan insektisida (bahan kimia yang membahayakan). Kalaupun penggunakan bahan kimia tidak dapat dihindari, maka gunakan insektisida biologis berbasis daun ataupun biji beberapa jenis tanaman yang bersifat inseksidal.

Penyakit yang paling sering muncul selain busuk akar adalah penyekait yang disebabkan oleh jamur dengan gejala serangan berupa noda gelap pada daun atau menutupi seluruh daun, sehingga dapat menyebabkan daun menguning dan mati. Penyakit ini dapat dikendalikan dengan menggunakan fungisida berbahan aktif mancozeb atau maneb.

\section{Waktu Panen dan Cara Panen}

Panenan TAKEDAPOT adalah berupa daun kelor. Daun kelor dapat dipanen (panen pertama) sekitar 34 bulan setelah pindah tanam bibit (berumur 1 bulan). Pada saat itu tanaman kelor telah memiliki tinggi batang sekitar 1,5-2,0 m dari permukaan tanah. Jika TAKEDAPOT tumbuh baik, maka panen dapat dilakukan rutin setiap 30-60 hari sekali.

Pemanenan daun tanaman kelor dilakukan dengan pemangkasan. Pada sistim TAKEDAPOT, pemanenan dilakukan dengan dua cara, yaitu memetik daun tanpa memotong batang atau pucuk, dan memanen daun sekaligus memotong bagian batang atau pucuk sepanjang 20-50 cm dari ujung cabang (apikal). Pemangkasan atau pemanenan pertama ini akan memicu pertumbuhan cabang lateral sehingga akan meningkatkan hasil daun panenan berikutnya. Efek pemangkasan, pada tanaman kelor tanpa pemangkasan akan tumbuh meninggi dengan sistim batang tunggal, dapat membentuk percabangan sehingga tentu akan meningkatkan hasil panen dan memudahkan proses panen. Tunas baru, nantinya dapat dipanen selanjutnya setelah 30-60 hari setelah panen pertama. Kemudian panen berikutnya dengan memotong sepanjang 30-50 cm cabang (batang) dari ujung tunas, atau meninggalkan batang cabang sepanjang $10-15 \mathrm{~cm}$ dari pangkal percabangan.

Waktu panen yang baik adalah jika dilakukan pada pagi atau sore hari. Jika panen akan dilakukan pada pagi hari maka sebelum dipanen daun dipastikan tidak basah atau berembun untuk menghindari pembusukan selama transportasi.

\section{Penanganan Awal Hasil Panen}

Hasil panen daun atau produk TAKEDAPOT adalah daun segar yang umumnya dapat dikonsumsi dalam dua hari setelah panen dan sering kali hanya dalam sehari. Daun sangat mudah rusak dan layu sehingga harus disimpan pada kondisi suhu dingin dan kelembaban tinggi untuk menghindari layu yang berlebihan. Jika proses atau pemanfaatannya akan ditunda sementara, maka jangan biarkan daun-daun kelor hasil panenan menumpuk. Jika menumpuk cukup lama, maka daun kelor akan rusak karena panas yang ditimbulkan akibat penumpukan tersebut. Sebaiknya daun kelor di-hamparkan dengan ketebalan satu-dua tumpukan daun.

Cara sederhana dan murah serta cukup efektif untuk mempertahankan kesegaran daun kelor hasil panen adalah dengan masukkan daun-daun hasil panen tersebut ke dalam kantong plastik, dan kemudian disimpan pada ruangan yang bersuhu sekitar $10-15^{\circ} \mathrm{C}$.

Jika proses pengeringan harus atau perlu dilakukan, maka proses pengeringan harus dilakukan dengan cepat. Pengeringan yang baik adalah dengan cara pengeringan udara mengalir tanpa terkena sinar matahari. Upaya ini ditujukan agar daun kelor mengering secara perlahan dan menghindari terjadinya degradasi vitamin oleh sinar ultraviolet dari matahari.

Secara sederhana, yang memungkinkan untuk dilakukan oleh petani ataupun masyarakat umumnya, ada tiga teknik pengeringan daun kelor yang dapat digunakan, yaitu:

1. Pengeringan pada rak-rak yang ditempatkan pada bangunan sederhana.

2. Pengeringan dengan cara menghamparkan daun-daun hasil panenan beralaskan tikar pada lantai bangunan.

3. Pengeringan dengan cara daun-daun kelor hasil panenan digantung pada bentangan tali. 


\section{KESIMPULAN}

Teknologi Tepat Guna TAKEDAPOT dapat dipersiapkan dengan harapan berfungsi sebagai suatu panduan dalam mempersiapkan sarana penyediaan sumber pangan sehat yang berkelanjutan paling tidak untuk keluarga, sebagai sarana pelestarian sumberdaya tanaman kelor, serta jika ditujukan sebagai element lansekap pekarangan, tanaman kelor dalam pot juga dapat diandalkan. TAKEDAPOT, dipandang sebagai sebuah solusi dari permasalahan yang sedang dihadapi oleh masyarakat yang memiliki lahan terbatas namun di lain sisi berkemauan bercocok tanam tanaman yang memberi manfaat bagi kehidupan sehari-hari. Ataupun sebagai solusi menghadirkan sayuran sehat di halaman rumah, dan sekaligus sebagai penghijauan pekarangan di perkotaan. Tanpa lahan yang luas, bercocok tanam kelor, si tanaman serba guna, masih dapat dilakukan. Pada masa pandemic COVID-19, TAKEDAPOT sangat bermanfaat tidak hanya sebagai sumber pangan sehat yang meningkatkan kekebalan tubuh.

Jika dibudidayakan dalam jumlah cukup banyak yang disertai dengan perawatan yang baik, maka kelebihan hasil panenan dapat dijual. Hal ini menjadi salah satu peluang usaha yang mendatangkan tambahan pendapatan bagi rumah tangga.

\section{DAFTAR PUSTAKA}

Anwar, F., Latif, S., Ashraf, M., Gilani, A.H., 2007. Moringa oleifera: A food plant with multiple medicinal uses. Phytother. Res., 21: 17-25.

Becker, K., and Siddhuraju P., 2003. Antioxidant Properties of Various Solvent Extracts of Total Phenolic Constituents from Three Different Agro-Climatic Origins of Drumstick Tree (Moringa oleifera) J. Agric Food Chem.51:2144-2155.

Fahey, J.W. 2005. Moringa oleifera: A Review of the Medical Evidence for its Nutritional, Therapeutic, and Prophylactic Properties. Part 1. Trees for Life Journal, 1:5 http://www.tljournal.org/article/phyo/20051201124931586

Foidl, N., Makkar, H.P.S., Becker, K., 2001. The potential of Moringa oleifera for agricultural and industrial uses. In: The miracle tree - the multiple attributes of Moringa. Church World Service, Dakar, Senegal. $45-76$.

Kementan RI. 2012. Pengembangan Kawasan Rumah Pangan Lestari (KRPL). Kementerian Pertanian SIKIB (Solidaritas Istri Kabinet Indonesia Bersatu)

Santoso, B.B. 2009. Pembiakan Vegetatif dalam Hortikultura. Unram Press. Mataram. 169h.

Santoso, B.B., I.G.M.A. Parwata, I.N. Soemeinaboedhy. 2017. Pembibitan Tanaman Kelor (Moringa oleifera Lam.) Arga Puji Press. Mataram. 87h.

Santoso, B.B., I.G.M.A. Parwata. 2018. Biji dan Teknologi Benih Kelor (Moringa oleifera Lam.). Arga Puji Press. Mataram. 90h.

Santoso, B.B. 2019. Teknologi Tepat Gunas - Teknik Penyiapan Benih dan Perbanyakan Tanaman Kelor (Moringa oleifera Lam.). LPPM-Unram Press.

www.cnbcindonesia.com

www.genpi.com 